УДК [378.015.31:17.022.1]:821

DOI:

Сергій Гуров, кандидат педагогічних наук, доиент кафедри англійської філології та методики викладання англійської мови Мелітопольського державного педагогічного університету імені Богдана Хмельницького

\title{
СУТНІСТЬ ДУХОВНО-МОРАЛЬНИХ ЦІННОСТЕЙ ОСОБИСТОСТІ У ФІЛОСОФСЬКО-ПЕДАГОГІЧНОМУ ДИСКУРСІ
}

У статті досліджено розвиток поняття “иінність” у філософському, педагогічному і психологічному контекстах, а також уточнено сутність поняття "духовно-моральних иінностей” як системи. Автором здійснено аналіз передумов виникнення проблеми виховання духовно-моральних иінностей особистості. Розглянуто основні наукові підходи до аналізу системи духовно-моральних иінностей. Представлено різноманітність тлумачень циих понять у різні історичні періоди. Підкреслено нерозривність зв 'язку понять “духовність” та “моральність” через прагнення науковців поєднати релігійний та світський характери розуміння феномену духовності.

Ключові слова: система духовно-моральних цүінностей; цүінності; аксіологічний підхід; виховання; студенти гуманітарних спещіальностей.

Jim. 14.

Serhiy Hurov, Ph.D.(Pedagogy), Associate Professor of the English Philology and Methods of Teaching English Department Melitopol Bohdan Khmelnytskiy State Pedagogical University

\section{THE ESSENCE OF SPIRITUALAND MORAL VALUES OF PERSONALITY IN THE PHILOSOPHICALAND PEDAGOGICALDISCOURSE}

The article analyzes the development of the concept "value" in the philosophical, pedagogical and psychological contexts, as well as clarifies the essence of the concept "spiritual and moral values" as a system. The author analyzed the background of the emergence of the problem of education of spiritual and moral values of the individual. The main scientific approaches to the analysis of the system of spiritual and moral values are considered in the article. Variety of interpretations of these concepts in various historical periods is presented. The unity of the concepts "spirituality" and "morality" is emphasized in the article; the author explains it by scientific tendency to combine the religious and secular character in comprehension of the spirituality phenomenon.

Consideration of the category "value" from philosophical point of view gives the author the opportunity to assert that it is an essence and a special type of ideological orientation of a person, one's valuable comprehensions about the ideals, goodness, morality of beauty and harmony, which are fixed in certain cultures. The system of spiritual and moral values has a complex character and a humanistic nature.

The author understands the system of spiritual and moral values of the individual as the guides for personality's social activity, aimed at achieving socially meaningful humanistic goals. The spiritual and moral values are, first of all, the guidelines, which serve as the ideal, a standard of what it should be like, which defines the relationship of the individual with the objects of reality and regulates its behavior and activities.

The article also raises the problem of the need to bring up the spiritual and moral values of students of humanities, the researcher insists that spiritual and moral values have a high educational potential of humanitarian knowledge.

Keywords: a system of spiritual and moral values; values; an axiological approach; an education; the students of humanitarian specialties.

П остановка проблеми. Якість університетської освіти є предметом постійних дискусій у науковому просторі. Різноманітні перетворення, нові концепції і технології передбачають цілеспрямовані зміни, що ведуть до розвитку компетентності майбутніх фахівців гуманітарних спеціальностей, їхніх знань, вмінь, досвіду професійної діяльності. Становлення внутрішньої сторони компетентної особистості студента, а саме його мотивів поведінки, ціннісних орієнтацій, життєвих переконань не може відбуватися без урахування аксіологічного підходу до формування особистості майбутнього фахівця. Для об’єктивної оцінки сформованості духовно-моральних цінностей особистості необхідним завданням, перш за все, постає: вивчення генези поняття “цінність” у філософському, педагогічному i психологічному контекстах, а також уточнення сутності “духовно-моральних цінностей” як системи.

Аналіз досліджень та публікацій. У 


\section{СУТНІСТЬ ДУХОВНО-МОРАЛЬНИХ ЦІННОСТЕЙ ОСОБИСТОСТІ}

\section{У ФІЛОСОФСЬКО-ПЕДАГОГІЧНОМУ ДИСКУРСІ}

наукових розвідках багатьох учених знайшли відображення проблеми значущості питань, пов'язаних $з$ розвитком світогляду особистості, становленням ii ціннісних орієнтацій та формуванням іiі духовно-морального потенціалу. Так, ми знаходимо фундаментальні наукові праці зарубіжних і вітчизняних вчених: Д. Леонтьєва, О. Кірьякової, Г. Лотце, В. Тугарінова, І. Беха, М. Боришевського, М. Євтуха, Є. Зеленова, І. Зязюна, Л. Сохань, Г. Шевченко, в основі яких лежить аксіологічний підхід до системи виховання особистості. Вчені стверджуть, що духовноморальні цінності мають високий виховний потенціал гуманітарних знань.

Мета статті. Вивчити розвиток поняття “цінність” у філософському, педагогічному і психологічному контекстах, а також уточнити сутність “духовно-моральних цінностей” як системи.

Виклад основного матеріалу. Категорія “цінність" є загальнонауковою категорією, яка використовується у філософії, етиці, соціології, психології та педагогіці для позначення об'єктів, явищ, їх властивостей, абстрактних ідей, що втілюють суспільні ідеали. Розгляд категорії “цінність" з позиції філософії свідчить про те, що вона є сутністю і особливим типом світоглядної орієнтації людини, ціннісними уявленнями про ідеали, моральність, добро, красу та гармонію, що встановлені в тій чи іншій культурі [9]. Аналіз літератури показав, що в сучасній педагогіці відсутній єдиний підхід до визначення природи і сутності духовно-моральних цінностей, незважаючи на те, що цей феномен активно вивчається вітчизняними та зарубіжними дослідниками. Різноманітність у тлумаченні поняття "цінності" в науці обумовлено, перш за все, відмінностями у розв'язанні проблеми співвідношення між суб' єктивно-об'єктивним та індивідуально-громадським стосовно цілісної структури особистості [13].

Звернемось до еволюційного розвитку цього поняття в свідомості людини: так, пояснення “ідеальним цінностям” одним 3 перших шукав філософ Платон. Він та Аристотель за основу цінностей беругь Божий авторитет, у Аристотеля знаходимо думку про те, що до одних речей люди прагнуть заради них самих, до інших як до засобів для перших. Саме цей філософ вводить поняття “вище благо” як “розумну діяльність душі”, що відповідає призначенню людини. Платон вважав що, мають бути якісь правила за якими, повинні жити громадяни Греції. Цими правилами він визначав цінності, серед яких він виявив мужність, справедливість, щастя, знання, і правдивість.
Філософ також стверджував, що люди, які жили у відповідності з цими цінностями мали характер більш високого порядку, i, в результаті, мали переваги у способі життя. Філософ відчував, що ігнорування цих цінностей призводить до суспільного зла та дисгармонії. Пізніше стоїки розуміли цінність як благо та ідею вищу [1].

В період Середньовіччя з'являється розуміння вищого блага як вищої цінності, якою є Бог. Криза античного світогляду вважається занепадом духовності в цілому, а минуле тлумачили з позиції гріховності людства. Звеличення Бога до вищої цінності в цей період пов'язано з ідеєю спасіння людства у майбутньому. Уявлення про цінності в Новий час змінюються та уточнюються. Р. Декарт стверджує, що вищим благом є людина як носій наукового знання.

У зазначеному вище історичному періоді феномен “цінність” докладно вивчає I. Кант, який розумів цінність як жорсткий припис, закон, веління (імператив) в протилежність особливому принципу (максими), він висловлює безумовну, неухильну повинність [6]. Однак, порівнюючи цінності 3 потребами, які забезпечують існування людини, то вони є продуктом людської соціальної діяльності, і у виборі цінностей людина має вільне право. Таким чином, він не тільки протиставив ціннісно-практичну свідомість людини теоретичній, а й вивів їі за межі гносеології.

Формулювання поняття “цінність" датується приблизно серединою ХІХ ст., і спочатку воно означало осмислення людиною навколишнього середовища. Р. Лотце у другій половині XIX ст. реалізує ідею про виокремлення особливої дисципліни - аксіології. Так з'являється аксіологічний підхід, завданням якого є з'ясування природи цінностей та їхнього місця в системі стосунків людини зі світом. Ф. Ніцше наполягав на тому, що в сучасному йому світові відбувався розпад цінностей, саме тому філософ закликав до утвердження нових чеснот, тобто цінностей майбутнього, до яких він відносив все те, що сприяло зростанню в людині почуттів сили, могутності і волі до влади [1].

Теорія цінностей (аксіологія) як напрям у західній філософії оформився у 20-50-х р. ХХ століття в працях відомих філософів - М. Шелера, Н. Гартмана, Р. Перрі, С. Пеппера та ін. Більшість 3 цих науковців вважали, що цінність має дві ознаки: по-перше - це будь-яке матеріальне або ідеальне явище, заради чого люди існують та здійснюють вчинки; по-друге - це внутрішня характеристика значущості людини, його поглядів, інтересів. Таким чином, загальними цінностями дослідники виділяють гуманістичні 


\section{СУТНІСТЬ ДУХОВНО-МОРАЛЬНИХ ЦІННОСТЕЙ ОСОБИСТОСТІ У ФІЛОСОФСЬКО-ПЕДАГОГІЧНОМУ ДИСКУРСІ}

загальнолюдські моральні цінності: добро, гуманність, чуйність, милосердя, толерантність, відповідальність.

А. Кірьякова з цього приводузазначає: поняття "цінність" є центральним в аксіології, саме воно поклало початок спеціальній області філософської науки, яка досліджує природу цінностей, їх місце в реальності, структуру ціннісного світу, розглядає взаємозв'язок різних цінностей між собою, їх відображення в структурі особистості. “Цінність" відноситься до числа таких загальнонаукових понять, методологічне значення якого є дуже важливим. Аксіологія, яка вивчає категорію “цінність” розглядає питання цінностей стосовно етики (Г. Лотце), психології - екзистенційна психологія - (Е. Джендлін, М. Хайдеггер), яка пояснює “цінність” як цілісність життя, пов' язує iii $з$ переживанням, та особливістю людини відчувати; гуманістична психологія (А. Маслоу), яка виділяє буттєві цінності як цінності повноти буття - добро, красу, справедливість, правдивість та самодостатність [7, 132 - 151].

Феномен цінностей знаходить своє обгрунтування в основних положеннях теорії цінностей, які надали В. Віндельбанд і Г. Ріккерт, в їхніх наукових працях цінності постають позаісторичним утворенням, що відображає вічний усвоїй трансцендентності світ, незалежний від свідомості людини. Базовими цінностями представники неокантіанства визначають “істину”, “добро” і “красу”, які є цілями самі по собі. Філософи наполягають на тому, що вони не можуть слугувати основою для інших цілей загальнолюдської ціннісної поведінки, ії мотивації, соціокультурних детермінант тощо [5, 14 - 17].

Вивчаючи феномен цінностей, В. Тугарінов стверджує, що цінність людині несуть ті явища в природі та суспільстві, які є потрібними і корисними для людей певного суспільства чи класу в якості дійсності, цілі або ідеалу. Так, за висловом вченого, людська цінність визначається трьома аспектами: 1) цінністю як значущістю, корисністю предметів та явищ; 2) цінністю як ціллю або ідеалом; 3) цінністю і як значущістю, i як ідеалом [12].

Об'єктивним критерієм цінності, на думку філософа, є мораль, виражена в моральних зразках. Вчений виділяє дві групи цінностей цінності життя - здоров'я, проживання власного життя, спілкування з іншими людьми - визначає 3 позицій соціальних і моральних цінностей, вказуючи, що спілкування повинно грунтуватися на взаємних інтересах, та цінності культури, які включають в себе матеріальні цінності, які служать в якості засобів задоволення матеріальних потреб; соціально-політичні - мир, свобода, безпека, справедливість, людяність, громадський порядок. Вони висловлюють задоволення як соціальних, так і моральних потреб через систему моральних зразків вчинків і поведінки; духовні - освіта, наука, мистецтво служать вихованню духовно-моральних цінностей особистості [12].

А. Здравосмислов вважає, що світ цінностей - це, перш за все, світ культури в широкому значенні цього слова, це сфера духовної діяльності людини, їі моральної свідомості - тих оцінок, в яких виражається рівень духовного збагачення особистості. Він відносить цінності цілком до сфери духовної культури. “Сукупність сформованих, усталених ціннісних орієнтацій утворюють свого роду центр свідомості, який забезпечує стійкість особистості, прийнятність певного типу поведінки і діяльності, виражену в спрямованості потреби та інтересів. В силу цього ціннісні орієнтації виступають важливим фактором, зумовлюючим мотивацію дій і вчинків особистості” [3].

Особливого значення для становлення теорії цінностей у філософії та педагогіці набули науковоаксіологічні ідеї, та виховні концепції відомих учених, так, дослідження філософів показують, що проблема виховання духовно-моральних цінностей хвилювала людство як в його історичному, так і культурно-моральному аспекті, розкриваючи приналежність людини до певної культури. Науковці пропонують значну кількість теорій і поглядів на духовно-моральні цінності, і виокремлюють різні моральні орієнтири, однак основними концепціями $є$ такі: екзистенціалізм (А. Камю, М. Хайдегер, К. Ясперс) що позиціонує і досліджує людину як унікальну духовну істоту, що здатна до вибору власної долі; аксіосферна теорія духовно-моральних цінностей (М. Каган, Л. Столович), яка грунтується на засадах ціннісного підходу; концепція соціальних, духовноморальних цінностей (Г. Іррлітц, А. Гусейнов, А. Здравосмислов); концепція діалектичного матеріалізмуна духовно-моральні цінності(В. Ленін, К. Маркс, Ф. Энгельс, Л. Фейєрбах) розглядає саму мораль як внутрішній революційний чинник, що мобілізує народ на поліпшення об'єктивних умов його життя і самого себе, світу своїх пристрастей, почуттів, помислів, мотивів та ідеалів.

Аналіз філософської та психолого-педагогічної літератури дозволяє стверджувати, що ціннісні оріснтації людини складають іï духовно-моральний стрижень. К. Ушинський підкреслював, що виховання духовно-моральних цінностей $є$ 


\section{СУТНІСТЬ ДУХОВНО-МОРАЛЬНИХ ЦІННОСТЕЙ ОСОБИСТОСТІ}

У ФІЛОСОФСЬКО-ПЕДАГОГІЧНОМУ ДИСКУРСІ

найважливішим завданням вихователя, фізичною і розумовою. Існування фізичної праці, важливішим за розвиток розумових здібностей. В педагогічній діяльності важливим є розуміння цінності як ідеалу, яку особистість прийняла для себе у вигляді поняття або настанови [8]. У науковому доробку К. Ушинського та А. Макаренко є переконливі свідчення того, що такі характеристики особистості як: чуйність, скромність, тактовність, щирість, вимогливість, дисциплінованість, індивідуальність, моральність, духовність мають цілеспрямовано виховуватися

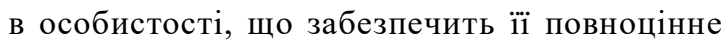
формування - як найвищого надбання суспільства $[8 ; 14]$.

Таким чином, цінності - це моральні та естетичні норми, які вироблені людською культурою в процесі історичного розвитку суспільної свідомості. Індивід засвоює систему цінностей в процесі соціалізації. Підсумовуючи вищеозначене, можемо стверджувати, що цінність тлумачиться як реальний предмет корисний для суб'єкта, як такий ідеал, що має значущість.

Щодо поняття “духовно-моральні цінності”, то, перш ніж надавати йому дефініції, необхідно визначитися з такими складними поняттями як: “духовність” і “моральність”. У В. Діденко знаходимо низку характерних рис для поняття “духовне": неминучий характер;спрямованість на ідеальне; те, що не стало зрозумілим в рамках реального буття; “прорив” духа за межі раціональності; відкритість до інновацій і різноманіття; опірність духа [2]. Духовністю $є$ дихання життя, стан самосвідомості людини, який виражається в ії думках, словах і діях. На думку вченого духовність є світоглядним підходом, що визначає первісність духовного у відношенні до матеріального, саме духовність має стати базовим принципом вибудовування міжособистісних стосунків. Духовність проявляється у бажанні людини будувати стосунки з оточенням на основі добра, істини, краси і гармонії. Найважливішим джерелом духовності людини є іiі сумління, а проявом духовності $-\epsilon$ любов.

На особливу увагу заслуговують філософські ідеї, написані у формі "Повчання дітям" Володимира Мономаха, де ми знаходимо обгрунтування таким духовно-моральним цінностям людини як: віра, надія, любов, патріотизм, ввічливість, мілосердя, терпимість, піклування, взаємодопомога, щире ставлення до людей. У своєму зверненні до нащадків, Володимир Мономах закликав не забувати доброго і навчатися нового. Він проголошував гуманістичні ідеї і наполягав на тому, що в основі життя людини має бути праця у своїй єдності між за Мономахом, забезпечує подальший розвиток розумової праці, яка, у свою чергу, веде людину до збагачення досвіду, духовності і сприяє діянню істини і сенсу [11].

Стосовно моралі, то це здатність людини діяти, думати і відчувати у відповідності до свого духовного начала, це способи передачі зовні свого внутрішнього духовного світу. В цілому, духовність і мораль є поняттями нерозривними, їх прийнято розглядати уєдності, через прагнення поєднати релігійний та світський характери розуміння духовності.

Мораль - це те, що реально існує, це духовнопрактичний спосіб оволодіння світом. Саме мораль відображає загальнолюдські цінності, правила людського існування, які людство вибудовувало протягом тисячоліть. Саме мораль надає орієнтири людині діяти у відповідності 3 прийнятими в томучи іншому суспільстві уявленнями про добро і зло, вона регулює людську поведінку.

Моральність пов'язується із великою сукупністю цінностей, принципів і норм поведінки людей. До моральних цінностей в сучасній науковій літературі відносяться: доброта, справедливість, чесність, щирість, вірність слову, гуманність, відповідальність, почуття власної гідності, милосердя, терпимість та скромність. На думку багатьох вчених, духовно-моральні цінності являють собою сукупність внутрішніх можливостей, потреб, ідеалів і засобів. Вони виражають систему ставлення особистості до дійсності і визначають мотиви вчинків, мети дій, завдань, пропонують загальний кодекс поведінки. Традиційні духовно-моральні цінності мають стійкий характер, вони переходять 3 одного покоління до іншого, вони не мають часового або просторового характеру вони спрямовані на збереження світу.

В концепції “морально-етичного нагляду за душею людини”, створеної відомим українським філософом Г. Сковородою йдеться про такі якості душі як: вдячність, моральність, розум, любов, терпимість, милосердя, на яких педагог має виховувати особистість [10]. Автор зазначав, любов, як вищий прояв духовності людини $є$ “найістотнішим джерелом іï щастя” [11].

Досить глибоко, на наш погляд, сутність поняття “моральні цінності” розкривається в дослідженнях А. Гусейнова та Г. Іррлітца. Вони розкривають моральність як спосіб соціальної регуляції, ціннісного ставлення до світу, суспільну форму відносин між людьми, як те, що залишається в міжособистісних відносинах. Це 


\section{СУТНІСТЬ ДУХОВНО-МОРАЛЬНИХ ЦІННОСТЕЙ ОСОБИСТОСТІ У ФІЛОСОФСЬКО-ПЕДАГОГІЧНОМУ ДИСКУРСІ}

міра гуманності, людяності суспільних відносин людей, які беруть моральний сенс тоді, коли вони орієнтовані на людину як вищу цінність. Моральні відносини фіксуються в поняттях моральної свідомості (добро, обов'язок, совість, справедливість).

Вагомим внеском у розвиток духовноморальних цінностей $є$ погляди М. Кагана. На його думку, відмінна риса їх полягає в тому, що особистісні смисли, системи цінностей індивіда не можна сформувати ні передачею повідомлень, ні прямою матеріальною взаємодією. Сам факт того, що вони є особистісними, підтверджує те, що вони мають сформуватися на основі переживань, а не раціональним шляхом [4].

Висновок. Таким чином, система духовноморальних цінностей має комплексний характер і гуманістичну природу. У рамках нашого дослідження ми розуміємо під системою духовноморальних цінностей особистості такі цінності, які стають орієнтирами для соціальної активності людини, спрямованої на досягнення суспільно значущих гуманістичних цілей. Духовно-моральні цінності-це, перш за все настанови та орієнтири, які виступають у якості ідеалу, еталону того, що має бути, які визначають стосунки особистості 3 об'єктами дійсності та регулюють іiі поведінку і діяльність.

Враховуючи виховний потенціал, цінності виступають вектором формування особистості, тому пріоритетним завдання сучасної вищої гуманітарної освіти має бути навчити студентів “по-справжньому” бачити, цінувати і зберігати вічні людські цінності як стратегічні орієнтири життя. Адже цінності складають духовну основу особистості та визначають сутність пї внутрішнього світу. В процесі здобуттям вищої освіти у студентів гуманітарних спеціальностей необхідно формувати ці внутрішні світоглядні переконання, що формують їхню життєвупозицію та поведінку. Духовно-моральні цінності виступають об’єднувальною ланкою між культурою суспільства і внутрішнім світом особистості. Саме завдяки духовно-моральним цінностям в людини реалізується прагнення до самовираження і самовдосконалення.

\section{ЛIТЕРАТУРА}

1. Анисимов С.Ф. Духовные ценности: производство и потребление / С.Ф. Анисимов. - Москва: Мысль, 1988. $-178 \mathrm{c}$.

2. Диденко В.Д. Духовная культура: Философия / В. Д. Диденко. - Москва, 1989. - 137 с.

3. Здравосмыслов А. Г. Потребности, интересы, ценности / А.Г. Здравомыслов. - Москва, 1986. - 223 с.

4. Каган М.С. Философская теория ценности/
М.С. Каган. - Санкт-Петербург: ТОО ТК “Петрополис", 1997. $-205 \mathrm{c}$

5. Карпенко І. П. Трансформація загальнолюдських цінностей в інформаційному суспільстві: автореф. дис. ... канд. філос. наук: 09.00.03 Соціальна філософія та філософія історії / Карпенко Інна Павлівна; КНУ ім. Тараса Шевченка. - Київ, 2004. - 17 с.

6. Кант И. Критика чистого разума / И. Кант. Москва: Наука, 1999. - 655 с.

7. Маслоу А. Новые рубежи человеческой природы / А. Маслоу. - Москва: Смысл, 1999. С. 132-151.

8. Макаренко А. С. Некоторые выводы из моего педагогического опыта / А. С. Макаренко. - Москва: Просвещение, 1971. - 270 с.

9. Осіпцов А. В. Генеза розвитку загальнолюдських цінностей особистості / А. В. Осіпцов // ScienceRise: Scientific Journal. - 2015. - T. 3, № 1 (8). - C. 53-58.

10. Сковорода Г. Твори: у 2 т. / Г. Сковорода. - Київ: Обереги, 1994. - Т. 1. -530 с.

11. Сластенин В. А. Педагогика: учеб. пособие для студ. высш. пед. учеб. заведений / В. А. Сластенин, И. Ф. Исаев, Е. Н. Шиянов; под ред. В. А. Сластенина. Москва: Академия, 2002. -576 с.

12. Тугаринов В. П. О ценностях жизни и культуры / В. П. Тугаринов. - Ленинград: ЛГУ, 1960. - 137 с.

13. Турченко В. Н. Трансформация ценностных ориентаций в современной России / В. Н. Турченко, Е. К. Казарина-Волшебная // Вестник учебнометодического объединения вузов России по образованию в области социальной работы. - М.: Издво РГСУ. - 2009. - № 1. - С. 123-128.

14. Ушинський К. Д. Про народність у громадському вихованні / К. Д. Ушинський // Вибрані педагогічні твори: у 2 т. - Київ: Рад. шк., 1983. -Т. 1. - С. 43-102.

\section{REFERENCES}

1.Anisimov, S.F. (1988). Duhovnye cennosti: proizvodstvo i potreblenie [Spiritual values: production and consumption]. Moscow: Mysl, 178p. [in Russian].

2. Didenko, V.D (1989). Duhovnaja kultura: Filosofija [Spiritual Culture: Philosophy]. Moscow, 137p. [in Russian].

3. Zdravosmyslov, A.G. (1986). Potrebnosti, interesy, cennosti [Needs, interests, values]. Moscow, 223p. [in Russian].

4. Kagan, M.S. (1997). Filosofskaja teorija cennosti [Philosophical theory of value]. St. Petersburg: LLP TC "Petropolis", 205 p. [in Russian].

5. Karpenko, I.P. (2004). Transformacija zagalnoljudskih cinnostej v informacijnomu suspilstvi [Transformation of universal values in the information society]. Extended abstract of candidate's thesis. Kyiv, 17p. [in Ukrainian].

6. Kant, I. (1999). Kritika chistogo razuma [Critique of Pure Reason]. Moscow: Nauka, 655 p. [in Russian].

7. Maslow, A. (1999). Novye rubezhi chelovecheskoj prirody [New lines of human nature]. Moscow: Smysl, pp. 132-151. [in Russian].

8. Makarenko, A.S. (1971). Nekotorye vyvody iz moego pedagogicheskogo opyta [Some conclusions from my pedagogical experience]. Moscow: Prosveshhenie, 270p. [in Russian]. 
9. Osiptsov, A.V. (2015). Geneza rozvitku zagalnoljudskih cinnostej osobistosti [Genesis of the development of human personality values]. ScienceRise: Scientific Journal. Vol. 3, no. 1 (8). pp 53-58. [in Ukrainian].

10. Skovoroda, G. (1994). Tvori: u 2 t. [Works: 2 volumes]. Kyiv: Oberi, vol. 1, 530 p. [in Ukrainian].

11. Slastenin, V.A., Isaev I. F. \& Shiyanov, E. N. (2002) Pedagogika: ucheb. posobie dlja stud. vyssh. ped. ucheb. zavedenij [Pedagogy: manual for a student of higher pedagogical institutions]. Moscow: Academy, 576 p. [in Russian].

12. Tugarinov, V.P.(1960). O cennostjah zhizni i kultury
[About values of life and culture]. Leningrad: LSU, 137 p. [in Russian].

13. Turchenko, V.N. \& Kazarina-Magic, E.K. (2009). Transformacija cennostnyh orientacij v sovremennoj Rossii [Transformation of value orientations in modern Russia]. Bulletin of educational-methodical association of Russian universities of education in the field of social work. Moscow: Izv-RGSU, no. 1, pp. 123-128. [in Russian].

14. Ushinsky, K. D. (1983). Pro narodnist u gromadskomu vihovanni [About the nationality in public education]. Selected pedagogical works: 2 Vol. Kyiv: Rad. Shk., vol. 1, pp. 43-102. [in Russian].

Стаття надійшла до редакції 27.04.2018

УДК 37.013 .46

DOI:

Тетяна Бешок, кандидат педагогічних наук, старший викладач кафедри педагогіки та психології Кременецької обласної гуманітарно-педагогічної академії імені Тараса Шевченка

\section{ФОРМУВАННЯ ПОЗИТИВНОЇ МОТИВАЦІЇ У СТУДЕНТІВ ЩОДО} ЗАСТОСУВАННЯ НАВЧАЛЬНО-ПІЗНАВАЛЬНИХ МЕДІАТЕКСТІВ

Устатті виділеноосновні складові, яківпливаютьна формуванняпозитивноїмотиваціїустудентівщодозастосування навчально-пізнавальних медіатекстів. Детально проаналізовано створену автором мотивачійну модель ефективного застосування медіаосвітніх технологій у професійній підготовиі майбутніх учителів, яка включає структуру, зміст, ефективність таособливості діяльності. Обтрунтовано необхідність розвитку навичок самостійногомисленняу студентів ізметою формування стійкоӥмотиваиіїдо сприймання тавикористання медіаосвітніх технологійупрофесійній діяльності.

Ключові слова: майбутні учителі; навчально-пізнавальні медіатексти; мотиваційна модель; медіаосвітні технологї; позитивна мотивачія.

Puc. 1. Jim. 5.

Tetyana Beshok, Ph.D.(Pedagogy), Senior Lecturer of the Pedagogy and Psychology Department Kremenets Taras Shevchenko Regional Humanitarian and Pedagogical Academy

\section{BUILDING MOTIVATION OF STUDENTS FOR APPLICATION THE EDUCATIONAL- COGNITIVE MEDIATEXTS}

The article deals with the problem of using Media Technologes for learning and personal growth. The main components of the article includes the information need for building the positive motivation of the students to use the educational and informative mediatexts. The author shows the ways of building the needs of future teachers of using Media Technologies. The author in details analised the authors' motivational model of media-ducational technologies which can be used in the training of future teachers, which includes the structure, content, performance and features of the activities. The model includes the following components: target (teaching to objectively perceive information from the modern media), content (development of a methodology, recording the clear content of conducting classes using media education technologies), operational-effective (effective use of methods and forms of educational process), stimulation -motivated (interest of the audience through the diversification of the educational material) and control and regulatory (correcting students' knowledge in the process of their training).

The article shows ways of building of student intrinsic motivation to master solid professional knowledge and skills in the field of media education by including Media-content modules focus on discipline pedagogical nature, methods of teaching of secondary school subjects and by implementing the course "Media-technology in the educational process". The article shows the necessity of development skills of independent thinking in students in order the form a stable perception and motivation to use media technologies in educational careers. It is proved that the using of diversified of audiovisual teaching and learning materials in the classroom and outside the classroom contributes to the formation of positive motivation of students for training, education, self-development, learning new things.

Keywords: the future teachers; educational-cognitive mediatexts; the motivational model of Media Technology; the positive motivation.

остановка проблеми. Глобалізаційні процеси, стрімке зростання обсягів та значення інформації зумовлюють необхідність запровадження інноваційної моделі розвитку суспільства, що потребує удосконалення вітчизняної системи педагогічної освіти. У 